Edubiotik: Jurnal Pendidikan, Biologi dan Terapan

ISSN 2528-679X (print), ISSN 2597-9833 (online)

Vol. 6, No. 02, September 2021, pp. $123-131$

Available online at:

http:/lejurnal.budiutomomalang.ac.id/index.php/edubiotik

Research Article

\title{
Developing of character science teaching tools integrated with the value of Qur'an for junior high school students
}

\author{
Muhammad Irwansyah, Magfirah Perkasa, Muchlis, Bakhtiar, Nikman Azmin
}

Biology Education, STKIP Bima, Nusa Tenggara Barat, Indonesia

Email: irwansyahdompu20@gmail.com*, magfirahperkasa@gmail.com, muchlisdarwis06@gmail.com, bakhtiarbima43@gmail.com, biologinikman@gmail.com

\begin{tabular}{ll}
\hline Article Information & \multicolumn{1}{c}{ ABSTRACT } \\
\hline Submitted: 2021-07-24 & The curriculum of 2013 places spiritual attitudes as the first competencies from \\
Accepted: 2021-12-17 & core competencies and social attitudes as the second. This indicates that a \\
Published: 2022-02-01 & spiritual and social attitude is needed to survive in the 21st century. Therefore, this \\
study was held with the aim to develop science teaching materials with integrated \\
character of the Qur'anic verses that valid and effective criteria. The type of \\
research that used in this research is adapted from Thiagarajan's developing \\
model which focused on defining, designing, and developing stages. The \\
instruments used are validation sheets for expert judgement and student response \\
questionnaires to collect spiritual character of the students. Based on the results \\
of the study, the science teaching materials with Islamic character interpretations \\
meet the valid criteria with the validity of RPP = 3.37, modules = 3.23 and LKS = \\
3.51. Meanwhile, based on the results of limited trials, it can be concluded that the \\
students' responses to science teaching materials with integrated character of the \\
Qur'anic verse are in the positive and very positive category. \\
Keywords: Character; learning tools; Qur'an; science
\end{tabular}

\section{INTRODUCTION}

The challenge in the system of education today is the rapid progress of science and technology which can change the cultural, ethical and moral order of students. As the result of technological advances, students have become familiar with various sources of learning messages either through television technology, cellphones or through internet technology. Sources of learning messages that are difficult to control will be able to influence cultural, ethical and moral changes in students. A society that used to uphold the values of politeness, ethics and culture, but this century there has been a generation 
of Indonesians who get angry easily and violate the rules and norms, such as the habit of watching pornographic films, dressing openly, consuming alcohol and drugs and even sadism (Muhaimin, 2013).

Many things can be used as benchmarks for a country to be said to be a developed country. One of them can be seen from the behavior patterns of the people who can act maturely on themselves and others. The phenomenon of adolescence that occurs shows that there is moral degradation currently being experienced by the Indonesian people. The future of a nation is actually held by its youth, which is none other than a society that is in their teens, therefore it is very important for this nation to improve the quality of its youth for a better Indonesia. The thing that causes moral degradation is due to globalization that is increasingly entering Indonesia. With the existence of globalization, it should be able to improve the morale of the people if it is balanced with knowledge and strong preventive actions from the community itself (Habibi, 2020).

As the result of moral degradation among Indonesia's generations, the Ministry of education and culture formulated a new curriculum, namely the curriculum of 2013. The curriculum of 2013 aims to create a productive, creative, innovative, affective Indonesian generation while still having faith to The Creator. Meanwhile, according to Okmarisa (2016), the curriculum of 2013 places spiritual attitudes in the first order of core competencies and social attitudes as the second. This proves that the curriculum of 2013 really provides room for improvement and development of student attitudes, especially improvement of spiritual and social attitudes. Therefore, it is time for teachers in schools to optimize the development of potential attitudes that exist in students, not just developing knowledge competencies. Emotional skills (emotional quotients) will be able to make students enthusiastic about learning, or will be liked by their friends at play, will also help students 20 years later when they become a professional. In addition, the results of Megawangi's 2010 show that of the 13 factors supporting success in the world of work, 10 factors are related to the quality of a person's character and 3 factors are related to intellectual intelligence.

Winarti (2015) states that the learning method by integrating Islam and science can be a solution to develop good character in students. The integration of religion and science has become a new

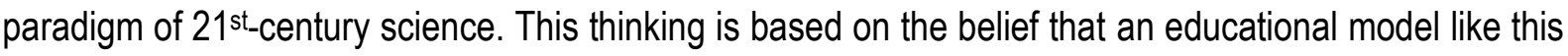
will be able to deliver graduates to have more complete knowledge, personality and insight who have the ability of spiritual quotion and Science and Technology (Purwaningrum, 2015). Many studies on the integration of the Al-Qur'an and Islamic values with science have produced the results which state that this integration can improve students' understanding, make it easier to analize parables and can enrich their insights because they can be proven directly with the senses (Listyono, 2018; Purwati et al., 2018; Sriatun et al., 2018; Suprihatiningrum, 2017).

Based on history, it proves that in the heyday of Islam with the spirit of the teachings of the Qur'an, Muslim scientists performed very impressively in every field of science such as Ibn Sina (medicine), AlKhawarizmi (mathematics), Ibn Al-Haytam (Biology) and Ibn Firnas (Physics). ) even western scientists such as Mark Zuckberg, R. Levy and George Sarton are motivated and acknowledge the intelligence of previous Muslim scientists. Because in the Qur'an there are hundreds of verses that motivate Muslims to think and research about science. What else was the first revelation that Allah swt sent to the Prophet Muhammad through the angel Jibril is Iqra '(read). The expert commentator Quraish Shihab explains that the word iqra', is taken from a root word which means to collect. From collecting various meanings, such as conveying, studying, exploring, researching, knowing the characteristics of something, and reading whether written or not are born. Meanwhile, in terms of the object, the iqra command includes everything that can be reached by humans. 
The Qur'an as the holy book of Muslims must be used in everyday life, including in science learning activities in schools so that there is no gap between the teachings of the Qur'an and the attitudes and personalities of students (Gosalam, 2012). However, based on the results of preliminary observations, the concept of integration of Islam and science has not been fully implemented by teachers in schools, including teachers in Bima City, NTB Province. The science teaching materials used by teachers in schools have not been seen to integrate science with the values of the Qur'an so that students do not get anything spiritual meaning from the science learning being taught. Even though according to the results of research by Syarimansyah et al. (2019), the use of integrated biology teaching materials with the values of the Qur'an can improve students' spiritual attitudes. Likewise with the research results of Irwansyah et al. (2014) that science learning tools based on an integrative approach (the integration of science in the Qur'an) can improve the attitudes and knowledge competencies of students. Some scientists have paradigms says that spiritual values can't be implement in other subjects especially science. Therefore, in this study, it is time for science teachers to develop teaching materials that are integrated with the verses of the Qur'an because these teaching materials have the opportunity to improve and develop the potential attitudes that exist in students so that they have provisions to live in the 21 st century.

\section{RESEARCH METHODS}

This research is a research development and the model is adapted from Thiagarajan's developing model which focused on defining, designing, and developing stages. The teaching materials developed in this study are the lesson plan, learning modules and students worksheet. Limited trials of developed teaching materials were carried out at MTsN 1 Bima in $8^{\text {th }}$-grade students that consists of 24 students in the odd semester of the 2020/2021 school year.

The quality of teaching materials expected in this study is measured using instruments based on quality aspects, including: (a) validity; measured by the expert validator's judgment (b) effectiveness; measured using questionnaires. The data were analyzed by using a formula and presented in descriptive views.

$$
\bar{X}=\frac{\sum_{i=1}^{n} \bar{A}_{i}}{n}
$$

$\bar{X}=$ total mean, $A_{i}=$ specific aspect means and $n=$ the number of aspects. The validity was classified based on the category that shown in Table 1.

Table 1. Validity Values Categories

\begin{tabular}{cc}
\hline Interval & Categories \\
\hline $3,5 \leq \mathrm{M} \leq 4$ & very valid $(\mathrm{VV})$ \\
$2,5 \leq \mathrm{M}<3,5$ & valid $(\mathrm{V})$ \\
$1,5 \leq \mathrm{M}<2,5$ & valid enough $(\mathrm{VE})$ \\
$\mathrm{M}<1,5$ & not valid (NV) \\
\hline
\end{tabular}

\section{FINDING AND DISCUSSION}

\section{Defining Stage}

The results of the defining stage show that the science teaching materials used by teachers are teaching materials purchased on the market and downloaded from the internet. The content of the science teaching materials is limited to material and description questions without being integrated with Islamic 
values that come from the Qur'an and the hadith of the Prophet Muhammad. Some studies also find that science learning carried out by teachers in school has not all integrated science learning with aspects of faith and piety (IMTAQ). Likewes the science textbooks used by teachers, there were not many that linked science learning with IMTAQ.

Some paradigms that are actually misleading believe that science runs independently and does not exist to do with religion at all. This is because the assumption that religion is just discussing a matter of worship, while science is synonymous with progress and innovation. However, this is evidenced by the many recent research results on the benefits of integrating the values of the Qur'an and science for students. The classical method on teaching the values of Qur'an separates it from other subjects become the dominant trend in religious schools today. This has led to stigma and debate about how reviving our Islamic learning legacy. Such false aspirations motivate Muslim reformers and educators to do so with several alternatives that seek to modernize the traditional system of legacy of long Islamic education, which is branded as a backward, unproductive, and most recently proliferating religious place intolerance into the modern, progressive and moderate education system, one of which is by integrating the values in the Qur'an with science (Ramdane, 2017).

Within in the Qur'an there are many verses that explain science that can increase students' faith to The Creator as the concept that to teach the students especially for Biology matter such as in the material of the human digestive system. The explanation regarding the function of food (Qs. Abasa: 24-31), food regulation (Qs. Al-Baqarah: 168), prohibition of consuming harmful foods (Qs. Al-lsra'a: 70), prohibition of consuming alcohol (Qs: Al - Baqarah: 219 and Al-Maidah: 90), the benefits of consuming halal and healthy food (Qs. Al-Baqarah: 172), and the benefits of drinking honey (Qs. An-Nahl: 69). According to Susanti \& Djukri, science teaching materials on ecosystem materials that are integrated with Islamic values can improve students' spiritual attitudes and student independence. Therefore, it is time for teachers who teach at Madrasah Tsanawiyah (MTs) to integrate Qur'an values in science subjects so that in the future generations will be born who are not only intellectually intelligent but they have good personalities or noble morals.

\section{Designing Stage}

The teaching materials developed in this study are the lesson plan, learning modules and students worksheet. The cover and some of those is shown in Figure 1, and the three teaching materials is more explained below:

a. Learning module

Learning module is a teaching unit arranged in a particular form for learning purposes. One of the objectives of teaching modules is to open opportunities for students to learn at their own pace. It is assumed that students will not achieve the same results at the same time and are not willing to learn something at the same time. The modules also gives the phase for students to learn at their own pace, because they use different techniques to solve certain problems based on their respective background knowledge and habits. The module developed was tailored to the needs of the students. In the learning module there is a procces to emphasize of character education that comes from the Qur'an value. Science learning matter is integrated with the Qur'anic verse as a solution to implement and prevent drug abuse cases caused by students of the city of Bima, NTB province.

The module is expected to provide opportunities for students to construct their own thoughts so that it affects students' attitudes. This is supported by Darmana (2013) statement which states that presenting the spiritual aspects of religion in science will not reduce its scientific level but will complement 
and strengthen each other which will be a means of achieving students' faith and piety. Science as an interconnected field of science sourced from God's revelation whether obtained through the prophet, critical thinking, or mutually integrated natural exploration to enhance scientific insight and human civilization. That there is a correlation between the rooted sciences and revelation (revealed by modern science) and local wisdom produces new sciences that are more humanist and ethical which are useful for benefit of living things.

b. Students worksheet

Students' worksheet are the student guides used to carry out investigative activities or problem solving. Student worksheets can be in the form of guides for cognitive development exercises or guides for developing all aspects of learning in the form of experimental or demonstration guides. It is containing assignments that must be done by students. This is generally in the form of instructions, steps to complete a task. A task that is ordered in a clear sheet of basic competencies that will be achieved.

In this study, student's worksheet is designed to contain various health problems of human digestive organs in real life with the hope that students can carry out scientific activities such as observations, investigations, experiments and students are expected to be able to provide solutions to various digestive organ health problems that arise in the community. In student's worksheet, there are higher order thinking skills (HOTS) questions that are adjusted to the conditions of junior high school's students. Scientific activities in the 2013 curriculum are set out in a scientific approach which has stages, namely observing, asking, exploring, associating and communicating. This scientific approach with the attribute "doing science". This approach facilitates the learning process to be more meaningful and detailed (Arini, 2020).
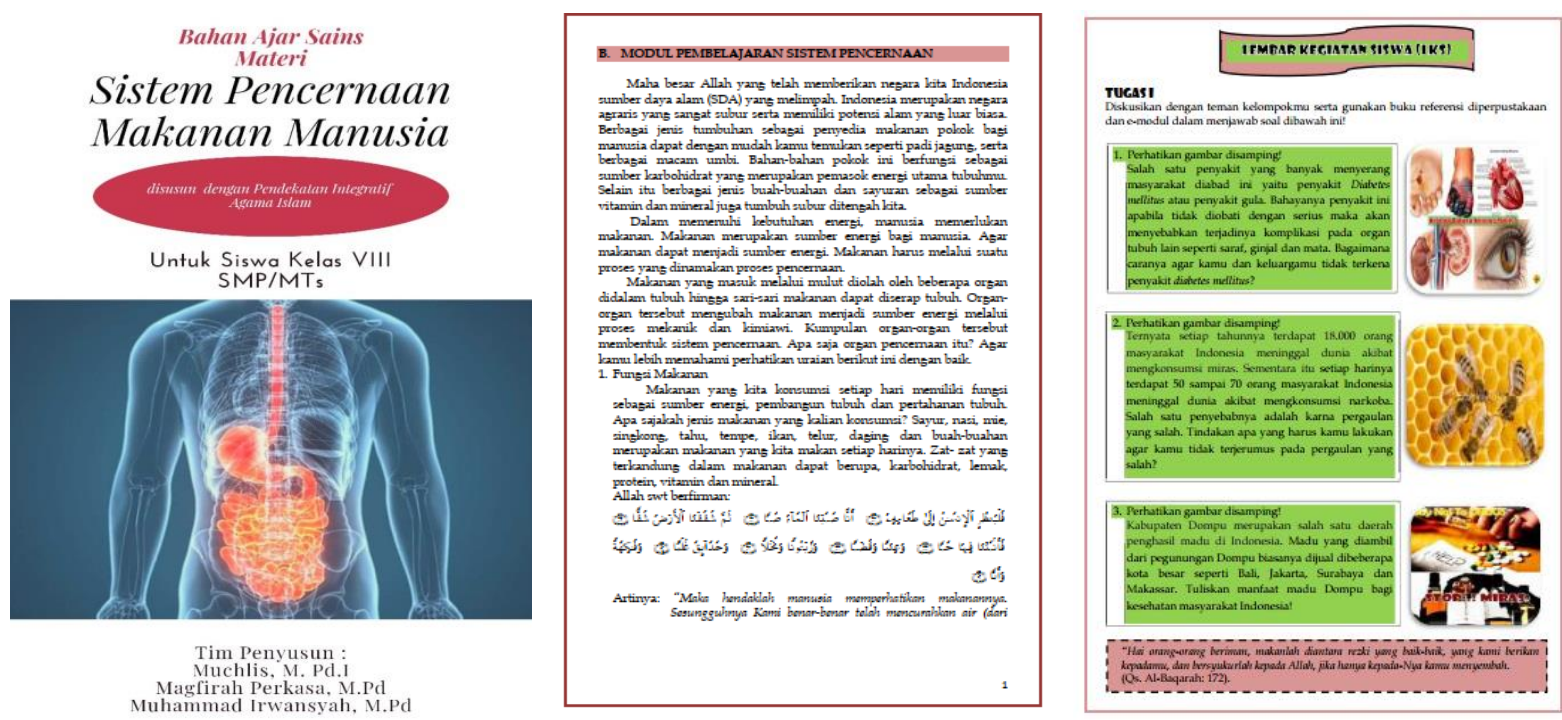

Figure 1. Human Digestive System Teaching Materials

\section{Development Stage}

a. The Result of Expert Validation

Expert judgement is required to review the specification of the product and to provide the improvement. This expert validation is carried out by a special expert who is capable and meets the requirement as it is. Science teaching materials with integrated character of Qur'an verses validated by experts include; (1) lesson plan; (2) learning module; (3) students' worksheet. The experts involved to validate the teaching materials developed are material experts and learning media experts. While the 
results of the validation of each science teaching material with an integrated character of the Qur'an verse can be seen in the Table 2 for lesson plan, Table 3 for learning module and Table 4 for students' worksheet as shown below:

1) Lesson plan validation results

Table 2. Data on The Results of Lesson Plan Validation

\begin{tabular}{cccc}
\hline No. & Assessment Aspects & $\overline{\boldsymbol{x}}$ & Information \\
\hline 1 & Achievement of goals & 3,30 & Valid \\
2 & Material coverage & 3,25 & Valid \\
3 & Model selection and learning steps & 3,50 & Very valid \\
4 & Media selection & 3,25 & Valid \\
5 & Assessments Instrument & 3,33 & Valid \\
6 & Grammar & 3,50 & Very valid \\
7 & Benefits & 3,50 & Very valid \\
& Total & 3,37 & Valid \\
\hline
\end{tabular}

2) Module validation results

Table 3. Module Validation Result Data

\begin{tabular}{cccc}
\hline No. & Assessment Aspects & $\overline{\boldsymbol{x}}$ & Information \\
\hline 1 & Construction of contents & 3,14 & Valid \\
2 & Display & 3,31 & Valid \\
3. & Completeness of the material & 3,67 & Very valid \\
4 & Conformity with other components & 3,00 & Valid \\
& (lesson plan dan students worksheet) & & Valid \\
5 & Grammar & 3,10 & Valid \\
6 & Benefits & 3,16 & Valid \\
\hline
\end{tabular}

3) Students worksheet validation results

Table 4. Students' Worksheet Validation Result Data

\begin{tabular}{cccc}
\hline No & Assessment Aspects & $\overline{\boldsymbol{x}}$ & Information \\
\hline 1 & Contents construction & 3,50 & Very valid \\
2 & Presentation technique & 3,64 & Very valid \\
3 & Completeness of content/material & 3,50 & Very valid \\
4 & Time & 3,50 & Very valid \\
5 & Language & 3,41 & Valid \\
6 & Benefits & 3,50 & Very valid \\
& Total & 3,51 & Very valid \\
\hline
\end{tabular}

Based on the results of the assessment of 2 expert validators, it was found that overall science teaching materials with integrated character of the Qur'anic verse were in the valid category with the following details (1) lesson plan was generally declared valid with a total mean value of $M=3.37$; (2) the learning module is generally declared valid with a total mean value of $\mathrm{M}=3.23$ and (3) teaching materials in the form of worksheets are generally declared very valid with a total mean value of $M=3.51$. Mustami (2015) and Perkasa (2016) state that the learning module developed can be concluded to be valid and useable because the development process is based on strong theoretical rationale and has internal consistency so that teaching materials have high reliability and consistency to collect data. Meanwhile, Sholihah and Kartika (2018) state that science teaching materials with integrated character of the Qur'anic verses can facilitate students 'independent learning besides that it can broaden students' insights not only 
in science material but can increase moral and religious values which in the end students always be grateful by carrying out all the commands of Allah and staying away from all the prohibitions.

\section{b. The Result of Limited Trials}

Limited trials are recommended to be carried out with a number of respondents ranging from 10 to 30 people. Limited trials were conducted to determine student responses to scientific materials with integrated character of the Qur'an verses that had been developed. Limited trials were carried out online by distributing student response questionnaires to eight grade students of MTsN 1 Bima city using the WhatsApp application (WA) and google form. The implementation time starts in July 2020. The data on limited trial results can be seen in the Table 5 which shown the persentage of student responses about the teaching materials that was arranged.

Table 5. Student Response Questionnaire Data

\begin{tabular}{ccc}
\hline No & Student response & Teaching materials \\
\hline 1 & Very positive & $33,33 \%$ \\
2 & Positive & $66,67 \%$ \\
3 & Negative & $0 \%$ \\
\hline
\end{tabular}

After data analysis was carried out, students' responses to science teaching materials with integrated character of the Qur'an verses were in the positive and very positive category. There were $66.67 \%$ students who gave positive responses and $33.33 \%$ students who gave very positive responses. It implies that the teaching tools used, especially the students sheets, are new things to students. In addition to assessing the learning materials developed, students also provide suggestions for improving future teaching materials. Suggestions for improvement from students such as clarity of image colors, clarity of writing verses of the Qur'an and hadith, and questions in the worksheets should be reduced. The integration of Qur'an values in the form of student worksheet is a new thing for students, because the combination of Qur'an and science values has never been introduced before.

\section{CONCLUSION}

After conducting research on the development of science teaching materials with integrated character of the Qur'an verse, it can be concluded that the teaching materials developed are valid and effective to be applied to junior high schools students. This is evidenced by the validity value of the lesson plan is 3.37 , the module is 3.23 and the validity value of the worksheet is 3.51 . While the limited trial results by looking at students' responses to science teaching materials with integrated character of the Qur'an verse were in the positive category with a value of $66.67 \%$ and very positive with a value of $33.33 \%$. The integration of Qur'an values in the form of student worksheet is a new things for students, because the combination of Qur'an and science values has never been introduced before. This learning tool provides new innovations to introduce the value of the Qur'an in science, as well as a good way to instill positive characters to the students.

\section{ACKNOWLEDMENT}

We would like to convey our gratitude to the Ministry of Research and Technology / National Research and Innovation Agency (Kemenristek / BRIN) and the leadership of STKIP Bima who helped fund and grant permission to conduct research through the Beginner Lecturer Research Grant (PDP). 


\section{REFERENCES}

Arini, W., (2020). Implementation of scientific approach in physics. Thabiea : Journal of Natural Science Teaching, 3(2), 151-161. http://dx.doi.org/10.21043/thabiea.v3i2.7958

Darmana, A., et.al., (2013). Pandangan siswa terhadap integrasi nilai tauhid melalui materi termokimia. Prosiding Semirata FMIPA UNILA Lampung. https://jurnal.fmipa.unila.ac.id/semirata/article/view/ 788

Gosalam, S., (2012). Urgensi Al-Quran dalam spengembangan sains \& teknologi. Makalah Disampaikan dalam Acara Orientasi Islam untuk Disiplin IImu (IDI) UIN Alauddin Makassar.

Habibi H, (2020). Hoax: Technological mechanisms, moral degradation, and critical loss of society's reason. Diadikasia Journal, 1(1), 93-102. https://doi.org/10.21428/8c841009.9f295293

Irwansyah M., Nurfathurrahmah \& Arifin., (2014). Pengembangan perangkat pembelajaran ipa terpadu berorientasi model pbl dengan pendekatan integratif untuk meningkatkan kompetensi sikap dan pengetahuan siswa. Oryza (Jurnal Pendidikan Biologi), 7(1), 36. https://doi.org/10.33627/oz.v7 i1.4

Listyono, Supardi, K.I., Hindarto, N., \& Ridlo, S., (2018). Methods of integrating islamic values in teaching biology for shaping attitude and character. Journal of Physics: Conf. Series, 938. https://iopscience. iop.org/article/10.1088/1742-6596/983/1/012178

Muhaimin., (2013). Rekontruksi pendidikan islam. Jakarta. Rajawali Pers.

Mustami, M.K., \& Irwansyah, M., (2015). Pengembangan lembar kerja peserta didik (Ikpd) berorientasi pendekatan saintifik di SMA. Lentera Pendidikan: Jurnal IImu Tarbiyah dan Keguruan, 18(2), 236. https://doi.org/10.24252/lp.2015v18n2a8

Niimati, R.A., \& Mursalin., (2018). Penerapan bahan ajar fisika berbasis nilai-nilai Al-Qur'an pada konsep gerak melingkar untuk meningkatkan hasil belajar siswa kelas $x$ madrasah aliyah. Prosiding Seminar Nasional Quantum Pendidikan Fisika UAD. http://seminar.uad.ac.id/index.php/quantum/article/view/ 250

Okmarisa, H., et.al., (2016). Implementasi bahan ajar kimia terintegrasi nilai spiritual dengan model pembelajaran problem based learning (pbl) berorientasi kolaboratif untuk meningkatkan hasil belajar siswa. Jurnal Pendidikan Kimia, 8(2). 130. https://doi.org/10.24114/jpkim.v8i2.4439

Perkasa, M., \& Aznam, N., (2016). Pengembangan SSP kimia berorientasi pendidikan berkelanjutan untuk meningkatkan literasi kimia dan kesadaran terhadap lingkungan. Jurnal Inovasi Pendidikan IPA, 2(1), 52. https://doi.org/10.21831/jipi.v2i1.10269

Purwaningrum, S., (2015). Elaborasi ayat-ayat sains dalam Al-Quran: Langkah menuju integrasi agama dan sains dalam pendidikan. Jurnal Inovatif, 1(1), 125. http://jurnal.staih.ac.id/index.php/inovatif/ article/view/16

Purwati, N., Zubaidah, S., Corebima, A.D., \& Mahanal, S., (2018). Increasing islamic junior high school students learning outcomes through integration of science learning and islamic values. International. Journal of Instruction, 11(4), 841. https://www.sciencegate.app/document/10.1297 3/iji.2018.11453a

Ramdane, T., \& Souad, M., (2017). Towards a new approach in the teaching of the holy Qur'an. International Journal of Humanities and Social Science, 7(10), 143-152. https://core.ac.uk/ download/pdf/300448794.pdf

Sholihah, N., \& Kartika, I., (2018). Pengembangan modul ipa terintegrasi dengan ayat Al-Qur'an dan Hadis. Lentera Pendidikan: Jurnal IImu Tarbiyah dan Keguruan, 21(1), 14. https://doi.org/10.2 4252/lp.2018v21n1i2

Sriatun., Linuwih, S., Sulhadi, \& Aninditya., (2018). Development of physics learning tools contains integration of Qur'an values. Advances in Social Science, Education and Humanities Research (ASSEHR), (247) 484. https://download.atlantis-press.com/article/55910682.pdf

Suprihatiningrum, J., (2017). Islam-science integration approach in developing chemistry individualized education program. Journal of Education and Learning, 11(4), 338-351. https://doi.org/10.11591/ edulearn.v11i4.7002 
Susanti, N., \& Djukri, D., (2018). Pengembangan modul biologi materi pokok ekosistem berbasis aktivitas siswa di pondok pesantren untuk menanamkan sikap spiritual dan kemandirian siswa. Jurnal Inovasi Pendidikan IPA, 4(1), 65. https://doi.org/10.21831/jipi.v4i1.5995

Syarimansyah., Irwansyah, M., \& Nehru., (2020). Pengaruh bahan ajar sistem reproduksi manusia terintegrasi nilai-nilai AI Qur'an terhadap sikap spiritual siswa. Pedagogos: Jurnal Pendidikan STKIP Bima, 2(1). 6. https://doi.org/10.33627/gg.v2i1.303

Winarti., (2015). Pengembangan perangkat pembelajaran fisika bermuatan integrasi islam-sains untuk menanamkan nilai-nilai spiritual siswa madrasah aliyah. Jurnal Pendidikan Fisika dan Keilmuan, 1(2). http://doi.org/10.25273/jpfk.v1i2.12 